\title{
Convective air drying of brown seaweed Bifurcaria bifurcata in thin layer configuration
}

\section{Arufe, S.; Sineiro, J.; Chenlo, F.; Moreira, R.}

Department of Chemical Engineering, Universidade de Santiago de Compostela, Rúa Lope Gómez de Marzoa, Santiago de Compostela, E-15782, Spain.

*E-mail of the corresponding author: ramon.moreira@usc.es

\begin{abstract}
Air drying kinetics of Bifurcaria bifurcata brown seaweed at 35, 50, 60 and $75^{\circ} \mathrm{C}$ were determined. Experimental drying data were modelled using twoparameter Page model (n, k). Page parameter $n$ was constant (1.28) at tested temperatures, but $k$ increased significantly with drying temperature from 35 to $60^{\circ} \mathrm{C}$ and was invariant at higher temperatures (up to $75^{\circ} \mathrm{C}$ ). Drying experiments allowed the determination of the critical moisture content of seaweed $\left(1.6 \pm 0.2 \mathrm{~kg}\right.$ water $\left.(\mathrm{kg} \text { d.b. })^{-1}\right)$. Mass transfer coefficients during constant drying rate period and effective coefficients of water diffusion during falling drying rate period were evaluated, assuming cyclindrical geometry and considering volumetric shrinkage.
\end{abstract}

Keywords: algae, diffusivity, drying kinetics, modelling, shrinkage 


\section{Introduction}

Bifurcaria bifurcata is a brown seaweed geographically distributed in the Western Europe and Sahara coasts. The main use is the extraction of compounds (alginates and other products) used by pharmaceutical, cosmetics and food industries [1]. Although the human consumption of this seaweed is not as extended as other seaweeds such as Laminaria spp., Undaria pinnatifida, its high content of polysaccharides, proteins and minerals [2] and antioxidants [3] makes attractive the use of this seaweed as food product. In fact, the direct human consumption worldwide in recent years is increasing.

Drying is a very employed operation in order to obtain stable food products whose storage as fresh product can be difficult. In the case of seaweeds, traditionally the water removal is carried out by solar drying, but the increasing demand of more homogenous and better quality dried products must be satisfied by means of the use of other industrial methods like convective hot air drying. In this sense, the experimental determination of the more adequate drying conditions is necessary to obtain a final dried product with acceptable characteristics. A scarce number of studies on mathematical modelling of drying kinetics of seaweeds can be found in literature. In example, Lemus et al. [4] studied the drying kinetics of the red seaweed Gracilaria chilensis and Vega-Gálvez et al., [5] the drying of brown seaweed Macrocystis pyrifera. However, no studies on drying kinetics of fresh Bifurcaria bifurcata were found. The aim of this work was to determine the drying kinetics of Bifurcaria bifurcata at different temperatures and the corresponding modelling of the drying periods.

\section{Materials and Methods}

Fresh brown Bifurcaria bifurcata seaweeds (4.59 $\pm 0.28 \mathrm{~kg}$ water $\left(\mathrm{kg}\right.$ dry solid) ${ }^{-1}$, d.b.) selected with similar sizes (100-150 mm length and 1.5-2.0 mm diameter) were dried in a hot air convective dryer (Angelantoni, Challenge 250, Italy), at four air temperatures (35, 50, 60 and $\left.75^{\circ} \mathrm{C}\right)$. Relative humidity $(30 \%)$ and air velocity $\left(2 \mathrm{~m} \cdot \mathrm{s}^{-1}\right)$ remained constant. Seaweeds were placed on a metallic mesh $\left(45 \times 45 \mathrm{~cm}^{2}\right)$ allowing the transversal air flow during drying. A thin layer configuration involving the use minimum amount of seaweeds to cover initially the drier tray (load density of $2.04 \pm 0.02 \mathrm{~kg} \cdot \mathrm{m}^{-2}$ ) was employed.

Samples were weighed using a balance (Cobos D-6000-CS, $\pm 0.1 \mathrm{~g}$, Spain), during drying until achieve a constant weight. All experiments were performed, at least, in triplicate.

Drying kinetics were modelled by Page model [6], Eq. (1):

$M R=e^{-k t^{n}}$

where $k\left(\mathrm{~min}^{-\mathrm{n}}\right)$ and $n(-)$ are the model parameters. The dimensionless moisture content or moisture ratio, $M R(-)$, was calculated by Eq. (2): 
$M R=\frac{X_{t}-X_{e q}}{X_{0}-X_{e q}}$

where $X_{t}$ is the moisture content (d.b.) at any drying time, $X_{0}$ is the initial moisture content (d.b.) and $\mathrm{X}_{e q}$ is the equilibrium moisture content of the sample (d.b.).

\subsection{Sample surface area and shrinkage determination}

Sample surface area and shrinkage of seaweeds were estimated following the same procedure.Samples (0.5-1.5 g) dried at several times were immersed into n-heptane at $21^{\circ} \mathrm{C}$. The initial volume $\left(V_{0}, \mathrm{~m}^{3}\right)$ of the samples and the volume at different drying times $(V)$, were measured applying Archimedes' principle.A volume shrinkage with moisture content $\left(V / V_{0}\right.$ vs $X$ ) relationship was obtained. External surface area of the monolayer was estimated assuming cylindrical geometry of the seaweed and the tray surface is fully covered initially. The initial radius of seaweed branches was determined $\left(2.3 \pm 0.310^{-3} \mathrm{~m}\right)$. Volume shrinkage was mainly governed by radius decrease $\left(\mathrm{L} / \mathrm{r}_{0}>100\right)$ and $\mathrm{Eq}$. (3) was obtained:

$\frac{V}{V_{0}}=\frac{\pi r_{x}^{2} L}{\pi r_{0}^{2} L} \rightarrow r_{x}=\sqrt{\frac{V r_{0}^{2}}{V_{0}}}$

where $L(m)$ is the length, $r_{0}$ and $r_{X}(m)$ the initial and the radius of sample at different moisture content. The surface area ratio of monolayer can be calculated by Eq. (4):

$\frac{S_{X}}{S_{0}}=\frac{2 \pi r_{X} L N_{S}}{2 \pi r_{0} L N_{S}}=\frac{r_{X}}{r_{0}}$

where $S_{X}\left(m^{2}\right)$ is the surface area of seaweed monolayer at each moisture content, $S_{0}$ the initial surface area of the monolayer and $\mathrm{N}_{\mathrm{s}}$ is the number of seaweed samples that can be placed in the monolayer $\left(\mathrm{L} /\left(2 \mathrm{r}_{0}\right)\right)$. Employing the Eq. (3), the relationship between surface area of seaweed monolayer and volumetric seaweed shrinkage resulted on Eq. (5):

$\frac{S_{X}}{S_{0}}=\sqrt{\frac{V}{V_{0}}}$

The determination of surface area of seaweeds monolayers allowed the specific drying rate, $w_{s}$ (kg water kg dry solid ${ }^{-1} \mathrm{~m}^{-2} \mathrm{~min}^{-1}$ ), evaluation by means of Eq. (6):

$w_{s}=\frac{1}{s_{X}} \frac{X_{t_{n-1}}-X_{t_{n}}}{t_{n}-t_{n-1}}$

The $w_{s} v s X$ curve was used for the critical moisture content $\left(X_{c}\right.$, d.b.) evaluation at tested temperatures and the end of the constant drying rate period.

\subsubsection{Constant drying rate period modelling}

During the constant drying rate period the coefficients of mass transfer $\left(\mathrm{K}_{\mathrm{t}}, \mathrm{m} \mathrm{s}^{-1}\right)$ and the convective heat transfer $\left(h_{t}, W \cdot \mathrm{m}^{2} \cdot K^{-1}\right)$, were determined by Eqs. (7) and (8): 
$w=\frac{X_{t_{n-1}}-X_{t_{n}}}{t_{n}-t_{n-1}}=\frac{K_{t} \rho_{\text {air }} a}{\rho_{s}}\left(Y_{i}-Y_{\text {air }}\right)$

$w=\frac{h_{t} a}{\Delta H_{v} \rho_{s}}\left(T_{i}-T\right)$

where $w\left(\mathrm{~kg}\right.$ water $\cdot \mathrm{kg}$ dry solid $\left.{ }^{-1} \cdot \mathrm{s}^{-1}\right)$ is the mass flow of evaporated water, $\mathrm{Y}_{\mathrm{i}}$ and $\mathrm{Y}_{\text {air }}(\mathrm{kg}$

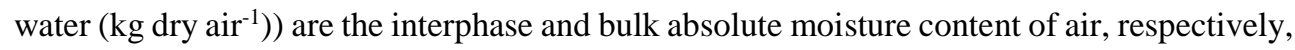
$\rho_{\text {air }}\left(\mathrm{kg} \cdot \mathrm{m}^{3}\right)$ is the air density at drying temperature, $\rho_{\mathrm{s}}\left(\mathrm{kg}\right.$ dry solid $\left.\cdot \mathrm{m}^{-3}\right)$ is the apparent density of seaweed layer, $a\left(\mathrm{~m}^{2} \cdot \mathrm{m}^{-3}\right)$ is the total interfacial surface (assuming water transfer by both sides of the layer) per unit of layer volume, $\mathrm{T}_{\mathrm{i}}$ and $\mathrm{T}\left({ }^{\circ} \mathrm{C}\right)$ are the interphase and dry temperature of air, respectively and $\Delta \mathrm{H}_{\mathrm{v}}\left(\mathrm{J} \cdot \mathrm{kg}^{-1}\right)$ is the latent heat of vaporization of water at the interphase temperature. The interphase properties $\left(Y_{i}\right.$ and $\left.T_{i}\right)$, during pre-critical drying period, were considered as the wet-bulb properties of the air employed for drying.

\subsubsection{Falling drying rate period modelling}

The falling drying rate period of drying was modelled employing the analytical solutions to Fick's diffusion equation to determine the effective coefficients of water diffusion through the sample under some assumptions [6]. Briefly, the distribution of the moisture within the product is uniform; at $\mathrm{t}>0$ surface reaches equilibrium moisture and all resistances to water removal are inside the material (the external resistances are negligible). Moreover, the shrinking effect on the characteristic dimension $\left(r_{x}\right)$ of seaweeds was taken into account. The fitting of the experimental data of the falling drying rate period was carried out employing the following ratio, Eq. (10):

$\frac{M_{t}}{M_{\infty}}=\frac{X-X_{e}}{X_{c}-X_{e}}$

where $\mathrm{M}_{\mathrm{t}}(\mathrm{g})$ is the amount of water removed at time $\mathrm{t}(\mathrm{min}), \mathrm{M}_{\infty}(\mathrm{g})$ is the total amount of water removed until the equilibrium is reached. The analytical solutions associated to the cylindrical geometry for short Eq. (11) and long Eq. (12) times are:

$\frac{\mathrm{M}_{\mathrm{t}}}{\mathrm{M}_{\infty}}=\frac{4}{\pi^{1 / 2}}\left(\frac{\mathrm{D}_{\text {eff }} \cdot \mathrm{t}}{r_{x}^{2}}\right)^{1 / 2}-\frac{\mathrm{D}_{\mathrm{eff}} \cdot \mathrm{t}}{r_{x}^{2}}-\frac{1}{3 \cdot \pi^{\frac{1}{2}}}\left(\frac{\mathrm{D}_{\mathrm{eff}} \cdot \mathrm{t}}{r_{x}^{2}}\right)^{3 / 2}$ when $0<\mathrm{M}_{\mathrm{t}} / \mathrm{M}_{\infty}<0.6$

$\frac{\mathrm{M}_{\mathrm{t}}}{\mathrm{M}_{\infty}}=1-\sum_{n=1}^{\infty} \frac{4}{\alpha_{n}^{2}} e^{-D_{e f f} \cdot \alpha_{n}^{2} \cdot t / r_{x}^{2}} \quad$ when $0.4<\mathrm{M}_{\mathrm{t}} / \mathrm{M}_{\infty}<1$

where $\alpha_{n}(-)$ are the roots of the first order Bessel function for each term $n$. In this case, three terms ( $\alpha_{1}, \alpha_{2}$ and $\alpha_{3}$ are 2.405, 5.520 and 8.654) of the Eq. (12) were considered enough to fit the experimental data. Water diffusivity values for short and long times were obtained using Microsoft Excel (Solver add-on) by means of nonlinear programming in which the root mean square error, $E_{\mathrm{RMS}}$, between experimental and calculated data is minimized. The final values of water diffusivity for the whole falling rate period were calculated by the weighted 
arithmetic mean (as function of the number of data for each time) of the water diffusivity obtained with the corresponding models for short and long times.

\section{Results and Discussion}

Figure 1 (left) shows the drying kinetics of Bifurcaria bifurcata at different temperatures. As it can be seen, a temperature increase from $35^{\circ} \mathrm{C}$ to $60^{\circ} \mathrm{C}$ decreased the drying time. The necessary drying time to achieve a MR of 0.03 was shortened from 100 to 60 min with no differences between drying at $60^{\circ} \mathrm{C}$ or $75^{\circ} \mathrm{C}$.
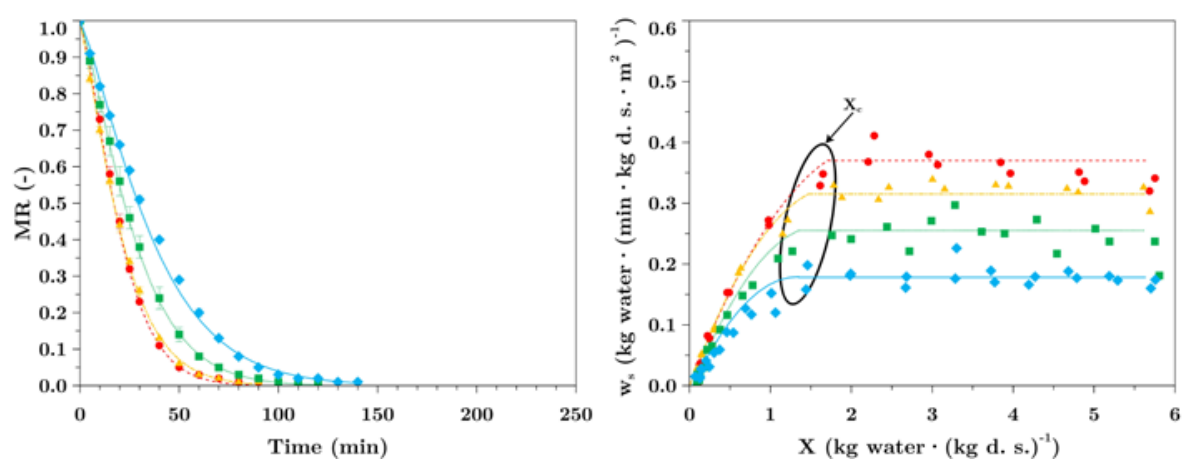

Fig. 1 Experimental drying (left) and specific drying rate curves (right) for Bifurcaria bifurcata at $35^{\circ} \mathrm{C}(\diamond), 50^{\circ} \mathrm{C}(\varpi), 60^{\circ} \mathrm{C}(\triangle)$ and $75^{\circ} \mathrm{C}(\bullet)$. Lines correspond to Eq. (13) (right) and to diffusional model (postcritical period) and Eq.(8) (precritical period) for cylindrical geometry (right).

Drying kinetics experimental data were satisfactorily $\left(\mathrm{R}^{2} \geq 0.999\right)$ fitted employing Page model, Table 1 . No significant differences existed between drying at $60^{\circ} \mathrm{C}$ and $75^{\circ} \mathrm{C}$ which means that regarding drying time, the drying at $60^{\circ} \mathrm{C}$ is more adequate. Moreover, $n$ parameter of Page model was constant for all drying temperatures. This fact, allowed the establishment of a unified model able to fit drying kinetics throughout the range of temperatures tested $\left(35-60^{\circ} \mathrm{C}\right)$ :

$M R=e^{-\left(-1.36 \cdot 10^{-3}-2.90 \cdot 10^{-4} T\right) t^{1.28}}$

Table 1. Values of the Page model parameters ( $k, n)$, Eq. (2) and statistical coefficients $\left(R^{2}, E_{R M S}\right)$ for drying curves of Bifurcaria bifurcata.*

\begin{tabular}{ccccc}
\hline $\left.\mathbf{T ~ (} \mathbf{}^{\mathbf{}} \mathbf{C}\right)$ & $\left.\mathbf{k} \cdot \mathbf{1 0}^{\mathbf{3}} \mathbf{( m i n}^{-\mathbf{n}}\right)$ & $\mathbf{n ~ ( - )}$ & ERMS $_{(-)}$ & $\mathbf{R}^{2}$ \\
\hline 35 & $8.7 \pm 0.08^{\mathrm{c}}$ & & 0.01 & 0.999 \\
50 & $12.8 \pm 1.15^{\mathrm{b}}$ & & 0.01 & 0.999 \\
60 & $17.8 \pm 0.65^{\mathrm{a}}$ & & 0.01 & 0.999 \\
75 & $18.6 \pm 0.77^{\mathrm{a}}$ & & 0.01 & 0.999
\end{tabular}

*. Data value of each parameter with different superscript letters in columns are significantly different $(\mathrm{P} \leq 0.05)$. 
Comparing with other brown seaweeds dried in similar conditions it can be said that Bifurcaria bifurcata has a similar behavior with drying temperature of the one observed for Fucus vesiculosus (FV) [7]. However, this behaviour was different of the one observed for other brown seaweed such as Ascophyllum nodosum and Undaria pinnatifida where temperatures higher than $60^{\circ} \mathrm{C}$ significantly decreased drying time [8].

\subsection{Sample surface area and shrinkage during drying determination}

The specific drying rate in thin layer configuration was evaluated using Eq. (6) considering that $\mathrm{S}_{\mathrm{x}}$ varied with seaweed moisture content according to a empirical non-linear relationship:

$\frac{s_{x}}{s_{0}}=\sqrt{-1.0+1.06 e^{-0.11 X}}$

The shrinkage of samples during drying significantly reduced the characteristic dimension $\left(r\right.$ ) of seaweeds. $r$ from $1.2 \pm 0.1 \cdot 10^{-3}$ to $5.8 \pm 0.3 \cdot 10^{-4} \mathrm{~m}$ at $\mathrm{X}_{\mathrm{c}}$. No significant differences on shrinkage behavior of seaweeds with temperature were observed indicating that these properties are more related to moisture content than to air drying rate. Experimental shrinkage data in terms of variation of characteristic dimension with time were correlated with moisture content as follows:

$r_{x}=\sqrt{-1.0+1.06 e^{-0.11 M R} \cdot\left(1.2 \cdot 10^{-3}\right)^{2}}$

where MR is evaluated by Page model, Eq. (1).

The specific drying rate $v s$ moisture content for all tested temperatures is shown in Figure 1 (right). It can be clearly observed the common drying periods. Namely, at high moisture content the constant drying rate period and below $\mathrm{X}_{\mathrm{c}}$ begins the falling rate period. No

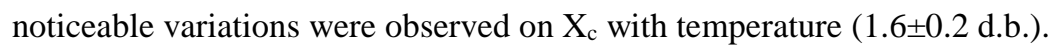

\subsection{Constant drying rate period: mass and heat transfer coefficients}

The modelling of constant drying rate period employing Eqs. (8) and (9) showed that no significant differences were found in the convective mass $\left(\mathrm{K}_{\mathrm{t}}\right)$ and heat $\left(\mathrm{h}_{\mathrm{t}}\right)$ transfer coefficients with temperature.

In the case of $K_{t}\left((21.8 \pm 2.0) \cdot 10^{-3} \mathrm{~m} \cdot \mathrm{s}^{-1}\right)$ the values are higher than those observed by da Silva et al. [9] who reported values of $K_{t}$ from $0.8 \pm 10^{-3}$ to $1.9 \pm 10^{-3} \mathrm{~m} \cdot \mathrm{s}^{-1}$ for pear drying in a forced air oven at higher temperatures (between 68 and $92^{\circ} \mathrm{C}$ ).

The corresponding values of $h_{t}\left(19.9 \pm 0.9 \mathrm{~W} \cdot \mathrm{m}^{-2} \cdot \mathrm{K}^{-1}\right)$ are in the range reported by Bird et al. [10] who indicated that a typical magnitude of convective heat transfer coefficient varies from 3 to $20 \mathrm{~W} \cdot \mathrm{m}^{-2} \cdot \mathrm{K}^{-1}$. 


\subsection{Falling drying rate period: effective coefficient of water diffusion through the seaweed}

During the falling-rate period the shrinking effect on the characteristic dimension was taken into account in order to obtain the water diffusion coefficient through the seaweed. Diffusional modelling of drying during post-critical period was satisfactorily performed $\left(\mathrm{R}^{2}\right.$ $>0.986$ and $\mathrm{E}_{\mathrm{RMS}}<0.03$ ) by diffusional model for cylindrical geometry (Eqs. (11) and (12)), Table 2.

Table 2. Effective coefficients of diffusion of water ( $\left.D_{\text {eff }}\right)$ and statistical coefficients $\left(R^{2}, E_{R M S}\right)$ for Bifurcaria bifurcata seaweed drying at different temperatures.*

\begin{tabular}{|c|c|c|c|}
\hline $\mathrm{T}\left({ }^{\circ} \mathrm{C}\right)$ & $D_{\text {eff }} 10^{12}\left(m^{2} \cdot s^{-1}\right)$ & ERMS (-) & $\mathbf{R}^{2}$ \\
\hline 35 & $12.43 \pm 0.64^{\mathrm{c}}$ & 0.02 & 0.988 \\
\hline 50 & $18.14 \pm 0.92^{b}$ & 0.03 & 0.998 \\
\hline 60 & $21.97 \pm 0.27^{\mathrm{a}}$ & 0.03 & 0.986 \\
\hline 75 & $20.35 \pm 1.31^{\mathrm{a}}$ & 0.03 & 0.989 \\
\hline
\end{tabular}

Water diffusion coefficient $\left(\mathrm{D}_{\text {eff }}\right)$ significantly increased with drying temperature below $60^{\circ} \mathrm{C}$, but no differences were observed between drying at $60^{\circ} \mathrm{C}$ and $75^{\circ} \mathrm{C}$. This trend of $\mathrm{D}_{\text {eff }}$ with temperature could be related to seaweed biopolymers could be washed away by the water flow and placed in the cell walls. This fact could make diffusion of water more difficult when drying above $>60^{\circ} \mathrm{C}$ takes place and consequently the typical increase of water diffusion with drying temperature is lost.

Compared with other works employing the same geometry, the obtained values were lower than those reported by Vega-Gálvez et al. [5] (2.8 to $\left.22.4 \cdot 10^{-9} \mathrm{~m}^{2} \cdot \mathrm{s}^{-1}\right)$ for drying temperatures from 30 to $70^{\circ} \mathrm{C}$ for Gracilaria chilensis seaweed. Despite of this difference, it can be said that the values are in the range of the typical values for food stuff $\left(10^{-9}\right.$ to $\left.10^{-11} \mathrm{~m}^{2} \cdot \mathrm{s}^{-1}[11]\right)$.

\section{Conclusions}

Bifurcaria bifurcata drying experiments in thin layer configuration (from $35^{\circ} \mathrm{C}$ up $75^{\circ} \mathrm{C}$ ) indicate that drying temperature increase up to $60^{\circ} \mathrm{C}$ significantly decrease drying time in order to achieve the same moisture content, but no differences exist between drying at $60^{\circ} \mathrm{C}$ $75^{\circ} \mathrm{C}$. There are no significant differences on mass transfer coefficient with drying temperature increase during the constant drying rate period. However, the water diffusion coefficient during falling drying rate period shows a significant increase from 35 to $60^{\circ} \mathrm{C}$, with no differences between drying at $60^{\circ} \mathrm{C}$ and $75^{\circ} \mathrm{C}$ which may be related to seaweed biopolymers washed away by the water flow and placed in the cell walls when drying above $>60^{\circ} \mathrm{C}$ takes place. 


\section{Acknowledgements}

The authors acknowledge the financial support of the Ministry of Economy and Competitiveness of Spain and European Regional Development Fund (ERDF) of European Union by the research project (CTQ 2013-43616/P).

\section{References}

[1] Mabeau, S.; Fleurence, J. Seaweed in food products: biochemical and nutritional aspects. Trends in Food Science \& Technology 1993, 4, 103-107.

[2] Gómez-Ordóñez, E.; Jiménez-Escrig, A.; Rupérez, P. Dietary fibre and physicochemical properties of several edible seaweeds from the northwestern spanish coast. Food Research International 2010, 43, 2289-2294.

[3] Nagai, T.; Yukimoto, T. Preparation and functional properties of beverages made from sea algae. Food Chemistry 2003, 81, 327-332.

[4] Lemus, R.A.; Pérez, M.; Andrés, A.; Roco, T.; Tello, C.M.; Vega-Gálvez, A. Kinetic study of dehydration and desorption isotherms of red alga Gracilaria. LWT-Food Science and Technology, 2008, 41, 1592-1599.

[5] Vega-Gálvez, A.; Tello-Ireland, C.; Lemus, R. Mathematical simulation of drying process of chilean gracilaria (Gracilaria chilensis). Ingeniare. Revista chilena de ingeniería 2007, 15, 55-64.

[6] Page, G. E. Factors influencing the maximum rates of air drying shelled corn in thin layers. Ph.D. thesis, Purdue University, 1949.

[7] Moreira, R.; Chenlo, F.; Sineiro, J.; Arufe, S.; Sexto, S. Journal of Food Processing and Preservation 2017, 41: e12997.

[8] Chenlo, F.; Arufe, S.; Díaz, D.; Torres, M.D.; Sineiro, J.; Moreira, R. Journal of Applied Phycology 2018, (in press) DOI 10.1007/s10811-017-1300-6.

[9] da Silva, A. N.; Coimbra, J. S.; Botelho, F. M.; de Moraes, M. N.; de Faria, J. T.; Bezerra, M.; Martins, M. A.; Siqueira, A. M. Pear drying: Thermodynamics studies and coefficients of convective heat and mass transfer. International Journal of Food Engineering 2013, 9, 365-374.

[10] Bird, R. B.; Stewart, W. E.; Lightfoot, E. N. Transport phenomena. John Wiley \& Sons Inc., 2nd ed. New York, 2002.

[11] Rizvi, S. Engineering properties of food, chap. Thermodynamics of foods in dehydration. Marcel Dekker: New York, 1986, 133-214. 